\title{
Phenotypic Variability of Ceratocystis paradoxa Isolated from North Western and Western Provinces of Sri Lanka and its Bio Control by Potential Bio-Control Agent; Trichoderma viride
}

\author{
D.L Jayaratne ${ }^{1}$ and M.T.A. Dayarathna ${ }^{2}$
}

\begin{abstract}
Coconut (Cocos nucifera) is an important economic crop in Sri Lanka; one of the world's largest exporters of coir fiber and coir products. Ceratocystis paradoxa is a pathogen causing stem bleeding, leaf and fruit rot in variety of crop plants including coconut. Since $C$. paradoxa is associated with coconut trees, there is an opportunity for the pathogen exist in coir and coir products as well. According to the quarantine requirements, this pathogen has to be free in coir and coir products that are exported from Sri Lanka. During this study the pathogen was isolated from the samples of coir collected from different locations in North Western Province and Western Province of Sri Lanka. Colony morphology and spore morphology were compared among these isolates. Bio-control and the sensitivity of the isolates to the antagonist were evaluated against Trichoderma viride. According to the results the pathogen was present in all the samples collected from different locations of the coconut growing triangle. The isolated colonies grown on Potato Dextrose Agar (PDA) plates were white in early stage but became black, one or two days later. The growing colonies produced two asexual spores; the endoconidia and chlamydospores. Endoconidia are formed in the conidiophores making long chains. They are thin-walled cylindrical 9-12 $\mu \mathrm{m} \times 4.8-7.2 \mu \mathrm{m}$ in size, yet two isolated from North Western Province had a smaller width of $2.4 \mu \mathrm{m}$ endoconidia. Chlamydospores are thick walled formed in short chains, dark color, and are mostly oval shaped, 9.6-16.8 $\mu \mathrm{m} \times 7.2-9.6 \mu \mathrm{m}$ in size, yet one isolated from North Western Province had a width of $4.8 \mu \mathrm{m}$. The chlamydospores are varied in morphology according to the geographical distribution of the pathogen. The variability of chlamydospore morphology predicts the genomic variability among the isolates. Biological control of $C$. paradoxa using $T$. viride was successful in all the isolates used in vitro studies. The experiments showed similar effects of $T$. viride on all $C$. paradoxa isolates as the biological control agent by killing the vegetative growth and losing the spore viability.
\end{abstract}

Keywords: Ceratocystis paradoxa, Thielaviopsis paradoxa, Trichoderma viride, endoconidia, chlamydospores, biological control agents

\footnotetext{
${ }^{1}$ Department of Microbiology, Faculty of Science, University of Kelaniya, Sri Lanka.

Email: dljayaratne@gmail.com

${ }^{2}$ Department of Cikitsa, Gampaha Wickramarachchi Ayurveda Institute, University of Kelaniya, Sri Lanka.

Email: tadayaratha@gmail.com
} 


\section{Introduction}

Ceratocystis paradoxa is a plant pathogen associated with palms as well as many other crops. An asexual reproductive stage of the pathogen is known as Thielaviopsis paradoxa. Due to infection of the pathogen the plant trunk either collapses on itself or the canopy suddenly falls off without warning. A common symptom observed on Cocos nucifera (coconut) is "stem bleeding; a reddish-brown stain that runs from the point of infection making a wound. The tissues surrounding the wound is quite soft in comparison to the surrounding trunk tissue. The disease was reported in Sri Lanka since 1906 and similar symptoms were observed in other coconut cultivating countries as well (Patch, 1906).

Sri Lanka exports coir and coir products that have a constant share of the country economy. Therefore, it is important to ensure that product quality is up to the required standards of the export market. Hence the pathogen should be free from the finished product. For elimination of the pathogen, methyl bromide fumigation is the most common treatment used by coir exporters and plant quarantine authorities, if they detect the pathogen in the samples. However, in recent years, methyl bromide is considered as an ozone depleting chemical and possible carcinogen and therefore, alternative methods of elimination of the pathogen are currently needed.

For the detection and identification of $C$. paradoxa, in coir samples, morphological characteristics methods of the pathogen are used. Colony morphology of the fungus in an artificial culture media and the spore morphology observed under the light microscope are accurate features for the detection and identification of the pathogen. However, the morphological methods are time consuming and less reliable compared to the molecular methods available.

Biological control is an effective method for the elimination of soil borne pathogens like C. paradoxa. The observations revealed that the pathogen can be successfully controlled by Trichoderma viridae. The biological control ability of $T$. viridae is due to several factors. $T$. viridae produces several groups of antibiotics to inhibit the growth of the pathogen. Apart from that mycoparasitism also occurred by which the pathogen is killed by mechanical and chemical means. Also Trichoderma species can inhibit or reduce the growth of the pathogens through competition for space, nutrients or oxygen. Trichorderma is fast growing and has the ability to colonize on a wide variety of substrates. This makes Trichorderma sp. efficient soil colonizers and bio-control agents. (Sanchez et al., 2007).

Thus the aim of the present study was to determine the phenotypic characteristics of Ceratocystis paradoxa isolated from the different locations of the coconut triangle in Sri Lanka and to evaluate the bio-control capability of $T$. viride on the pathogen isolates to eliminate the pathogen as an alternative to the chemical and physical treatment methods.

\section{Materials and methods}

\section{Sample collection}

Coir and coir dust samples were collected from sixteen locations in North western province and Western province of Sri Lanka to isolate the pathogen. The positive control reference culture was obtained from the microbial culture collection of the National Plant Quarantine Service, Katunayake. All the field samples were collected using sterile spades into clean new polythene bags separately and labeled properly.

\section{Isolation of $C$. paradoxa from coir and coir dust samples}

The ten-fold dilution series were prepared in sterile distilled water using each sample. The spread plate technique was used to inoculate PDA plates using the sample dilutions $10^{-1}$ to $10^{-4}$ to isolate $C$. paradoxa colonies on PDA plates. The inoculated plates were incubated at room temperature $\left(28 \pm 1^{\circ} \mathrm{C}\right)$ for two days. The well separated colonies were counted to enumerate the population density of the pathogen in different locations (Table 1). These colonies were then sub-cultured on PDA to obtain pure cultures of $C$. paradoxa. 


\section{Morphological variations of the different isolates of $C$. paradoxa}

The slide culture technique was used to determine mycelial and spore morphology of the isolates. The ocular micrometer method was used to measure the size of endoconidia, chlamydospores, conidiophores and vegetative mycelia of the isolates. The isolates were identified following the key outlined by Coomaraswamy (1979).

The effects of Trichoderma viride as an antagonist to control of $C$. paradoxa

The dual culture technique developed by Dennis and Webster (1971) and cited in Sanchez et al., 2007 was used. The Trichoderma viridae isolate was obtained from the Microbial Culture Collection Center of the Department of Microbiology, University of Kelaniya, Sri Lanka. The isolate was characterized by using the identification key published by Coomaraswamy et al., (1981).

Petri dishes (9 $\mathrm{cm}$ diameter) containing 15 $\mathrm{ml}$ of PDA were inoculated with mycelial discs $(5 \mathrm{~mm})$ taken from actively growing edges of 3day old colonies of the antagonist. Other agar discs of $5 \mathrm{~mm}$ were taken from each of the isolate and placed $5 \mathrm{~cm}$ apart from the antagonist in separate plates on the surface of the agar medium. The plates were incubated at room temperature $\left(28 \pm 1^{\circ} \mathrm{C}\right)$ under condition of light for 7 days. The time for the first contact between the antagonist and the pathogen, and the advance of antagonism and the pathogen colony were measured. Control plates were prepared by inoculating only $C$. paradoxa.

Determination of the antagonistic effect of $T$. viride on $C$. paradoxa spore viability

The spores of the antagonist and the pathogen isolates were scraped off from the PDA plates using sterile glass slides separately. The spore suspensions $\left(10^{7} \mathrm{CFU} / \mathrm{ml}\right)$ for each of the pathogen isolates and for the antagonist were prepared in sterile distilled water. The spore suspensions of the pathogens were individually mixed with equal volumes of the spore suspension of the antagonist. A volume of $0.1 \mathrm{ml}$ of the inoculum from each of the spore suspensions were poured onto PDA plates separately and spread evenly on the agar surface using sterile glass spreaders. The plates were incubated at room temperature $\left(28 \pm 1{ }^{\circ} \mathrm{C}\right)$ for two days. Germination of spores and the growth of both fungi, the antagonist and the pathogen isolates were observed on PDA plates in hourly intervals and photographed.

Antagonistic effect of diffusible, non-volatile metabolites produced by $T$. viridae on the mycelial growth of $C$. paradoxa

The method was adapted from the procedure described by Dennis and Webster (1971) cited in Sanchez et al., 2007.

A sterile cellophane membrane $(9 \mathrm{~cm}$ diameter) was placed on the surface of PDA plates containing $25 \mathrm{ml}$ of the medium. A disc of $5 \mathrm{~mm}$ mycelial obtained from actively growing edges of a 3-day old colony of $T$. viridae were placed in the center of each PDA plate. The Petri dishes were incubated for 2 days at $37^{\circ} \mathrm{C}$ in dark. After the incubation, the cellophane membranes with the fungal mycelia were removed from each plate. The $5 \mathrm{~mm}$ mycelial discs, taken from actively growing edges of 3day old colonies of $C$. paradoxa isolates were separately placed on the center of each plate in the same position where the antagonist $T$. viride isolate was grown. The plates were incubated at $37^{\circ} \mathrm{C}$ in dark for 4 days. The diameter of each fungal colony was measured. The controls were prepared by placing a $5 \mathrm{~mm}$ mycelia disc of $C$. paradoxa instead of the antagonist. Each treatment was replicated four times.

\section{Results and discussion}

According to the quarantine requirements coir and associated products should be free from C. paradoxa. But the present investigation revealed that the samples collected from the coconut growing triangle (Figure 1) are contaminated with $C$. paradoxa. The population density of the pathogen varied from 30 to 100 $\mathrm{CFU} / \mathrm{g}$ or more than $100 \mathrm{CFU} / \mathrm{g}$ in different samples (Table 1).

Moreover, the prevalence of the pathogen in the sugarcane growing areas of the country was recorded by Egan in 1961. The infection of 


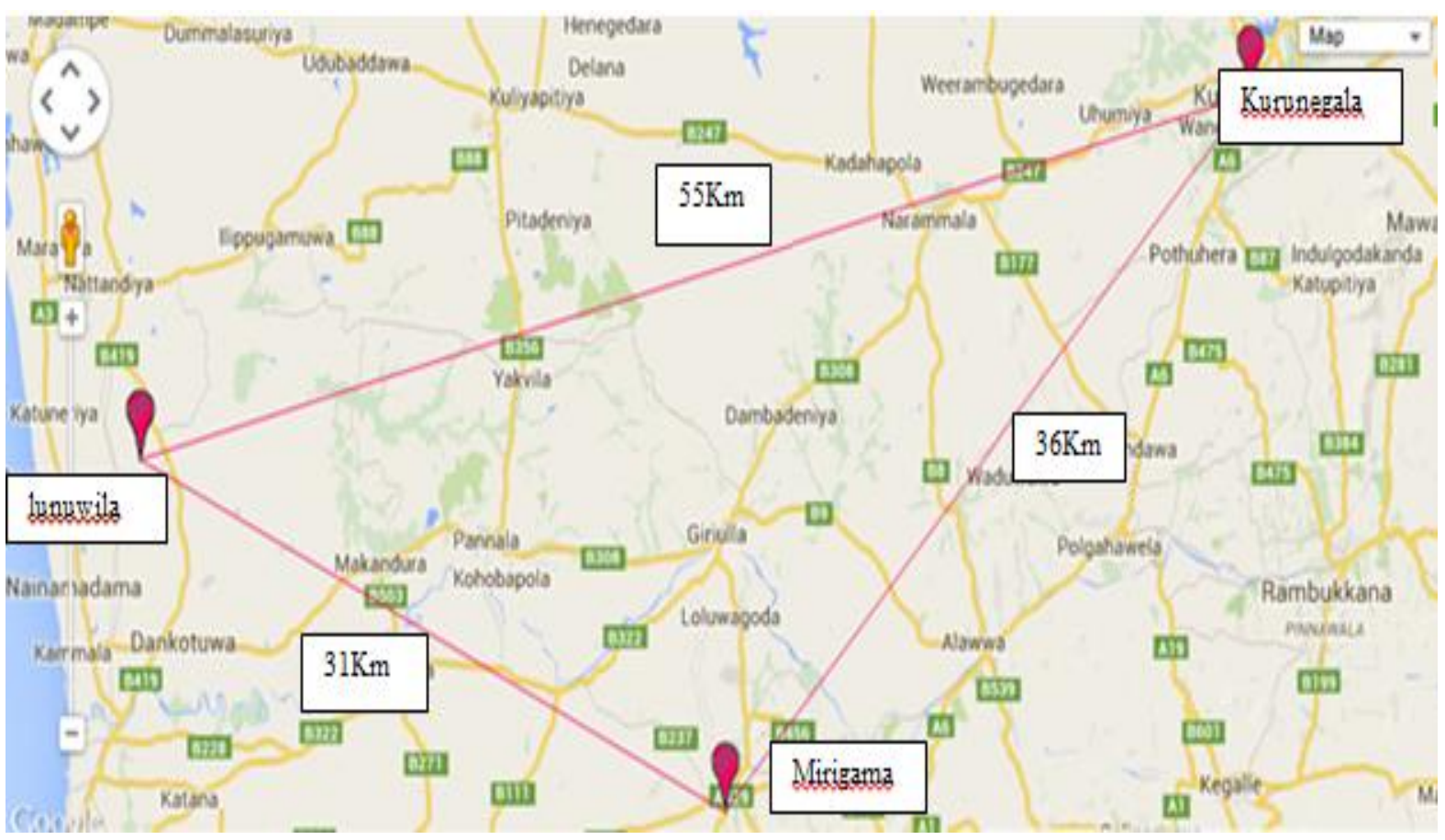

Figure 1. The Map showing the sample collection sites and the aerial distance between the sites

Table 1. The population density of $C$. paradoxa in the sample collection sites of the coconut growing triangle in Sri Lanka

\begin{tabular}{|c|c|c|c|}
\hline Province & Location & Isolate & C. paradoxa CFU/g of a sample \\
\hline \multirow{11}{*}{ North Western } & \multirow{3}{*}{ Lunuwila } & $\mathrm{Lu} 1$ & uncountable \\
\hline & & Lu 2 & 40 \\
\hline & & Lu-CR 5 & 50 \\
\hline & \multirow[t]{2}{*}{ Dunkannawa } & Du 3 & uncountable \\
\hline & & Du 4 & 60 \\
\hline & \multirow{6}{*}{ Kurunegala } & $\mathrm{Ku} 6$ & 100 \\
\hline & & $\mathrm{Ku} 7$ & 10 \\
\hline & & $\mathrm{Ku} 8$ & 100 \\
\hline & & $\mathrm{Ku} 9$ & 40 \\
\hline & & $\mathrm{Ku} 10$ & 50 \\
\hline & & $\mathrm{Ku} 11$ & Uncountable \\
\hline \multirow{5}{*}{ Western } & \multirow[t]{5}{*}{ Mirigama } & Mi 12 & 30 \\
\hline & & Mi 13 & 42 \\
\hline & & Mi 14 & 38 \\
\hline & & Mi 15 & 50 \\
\hline & & Mi 16 & 30 \\
\hline $\begin{array}{l}\text { National Plant } \\
\text { Quarantine }\end{array}$ & Katunayake & Ref 17 & Reference culture \\
\hline
\end{tabular}


the pathogen was reported even before 1906 by Patch in the coconut growing regions of Sri Lanka stating that the stem bleeding disease of coconut caused by $C$. paradoxa was first reported in the country (Dulce et al., 2009). These historical evidences are sufficient to believe that the island wide distribution of the pathogen with or without causing the disease in palm trees and other susceptible hosts. The parallel evolution of the pathogen with its natural hosts may not cause severe infections but survives causing mild infections and sporadic disease incidences. This situation makes high inoculum potential of the pathogen in the crop environment leading to serious problems in coir and coir product exportation from Sri Lanka.

\section{The spore morphology and vegetative mycelia of $C$. paradoxa isolated from coir and coir products}

The pathogen isolated in PDA produced two different types of asexual spores; endoconidia and chlamydospores. Endoconidia were prominent when the cultures were new and with the aging of cultures chlamydospores were predominant. There were no differences in the structure of endoconidiophores of all the isolates. The endoconidiophores got enlarged at the base when releasing endoconidia (Figure 2).

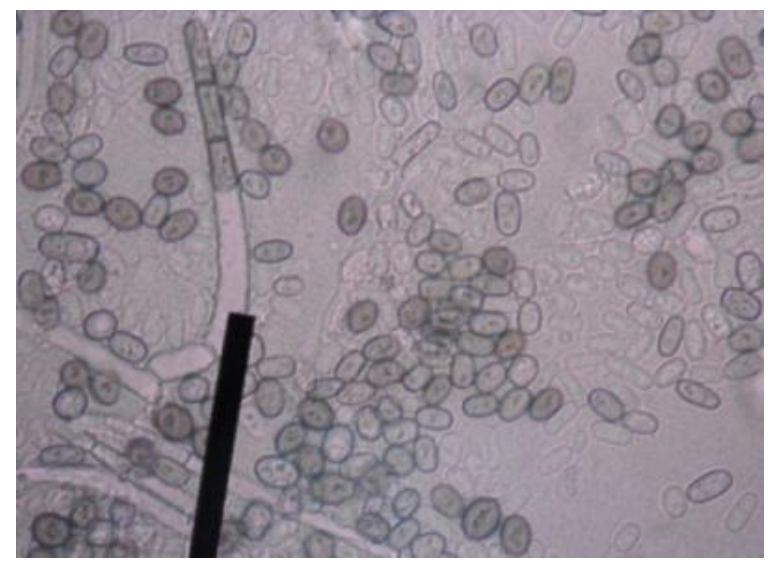

Figure 2. Endoconidiophore and endoconidia of C. paradoxa

All the isolates produced hyaline, cylindrical, thin walled endoconidia; $9-12 \mu \mathrm{m}$ in length and 4.8-7.2 $\mu \mathrm{m}$ in width (Figure 3 ). These sizes comply with the range stated in the published literature (Moutia \& Saumtally, 1999; Ploetz, 2008) except for the two isolates; Ku 6 and $\mathrm{Ku} 7$ isolated using the samples obtained from Kurunegala of North Western province. These isolates produce hyaline, thin-walled, cylindrical conidia remarkably smaller in size; 6$2.4 \mu \mathrm{m} \times 2-5.5 \mu \mathrm{m}$.

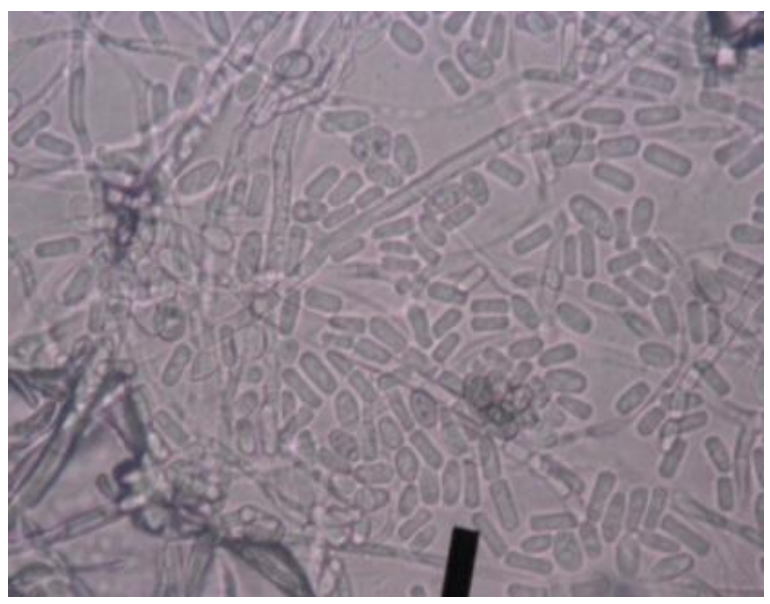

Figure 3. The endoconidia and the vegetative mycelium shown similar width in Kurunagala and Mirigama isolates of C. paradoxa

The chlamydospores are thick walled, light brown to dark brown and basically oval in shape. They were produced in older cultures ensuring the long-term survival of the pathogen in soil (Ploetz, 2008; Moutia \& Saumtally, 1999). The oval shape is prominent in Kurunegala isolates and Mirigama isolates. However, Lunuwila and Dunkannwa isolates produced oblong chlamydospores that are distinct from the above mentioned isolates. The reference culture $\mathrm{Rf} 17$ collected from National Plant Quarantine Service Katunayake, contained slightly oval chlamydospores (Figure 4, A, B and C). Accordingly, three different morphological types of chlamydospore are produced by these isolates.

Except, for the isolate Du 3 from Lunuwila of North Western province, which produced chlamydospores in smaller width size; 9.6 X 4.8 $\mu \mathrm{m}$, all the other isolates were in the range of the length 9.6-16.8 $\mu \mathrm{m}$ and the range of the width 7.2-9.6 $\mu \mathrm{m}$ that comply with the available literature (Moutia \& Saumtally, 1999). 

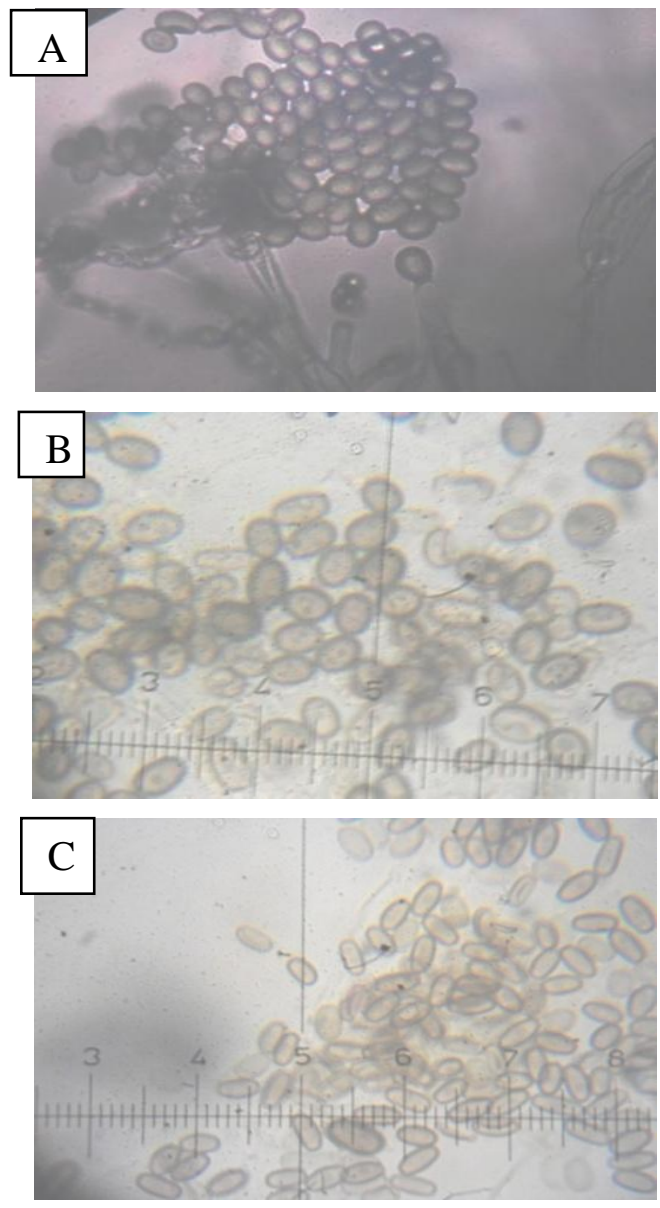

Figure 4. The chlamidospore morphology of the different isolates of $C$. paradoxa.

(A) Slighty oval chlamydospores of ref. culture RF 17, (B) Oval chlamydospores of Kurunagala and Mirigama isolates,

(C) Oblong chlamydospores of Lunuwila isolates

The phenotypic comparison of $C$. paradoxa isolates collected from coconut growing triangle of Sri Lanka

Figure 5 prepared by Minitab- 15 for all the isolates estimates their evolutionary relationship. Accordingly, isolates Lu 1, Lu 2, Du 4 and Du 5 obtained from Lunuwila and Dunkannawa of North Western Province shows 100\% similarity among them where as isolates $\mathrm{Ku} 8, \mathrm{Ku} 9, \mathrm{Ku}$ 11, Mi 12, Mi 13, Mi 14 and Mi 15 obtained from Kurunegala of North Western Province and Mirigama of Western Province again shows $100 \%$ similarity making two distinct major clusters among these isolates. A third cluster, isolate 3 of Lunuwila/Dunkannawa and isolates $6 \& 7$ of Kurunagala/Mirigama are more closely related than to Lunuwila/Dunkannawa cluster showing $52.86 \%$ similarity while distinctively different from Kurunagala/Mirigama cluster displaying only $29.29 \%$ similarity. Remarkably, isolate 10 shows only $29.29 \%$ similarity to the above mentioned three clusters. The isolate produce oval and black chlamydospores of 9.6 to $16.8 \times 7.2$ to $9.6 \mu \mathrm{m}$. These observations revealed that there may be four distinctive evolutionary lines from the immediate ancestors of $C$. paradoxa inhabited in the coconut growing triangle of the investigated area. The two major clusters, Lunuwila/Dunkannawa and Kurunagala/Mirigama appear to be the coevolution of the pathogen with the host in natural agricultural environment with or without least involvement of human activities. The cluster of isolates $3,6,7$ seems to be the man made distribution of the pathogen within these locations. The highly distinctive 'isolate 10' shows an extraordinary evolutionary trend.

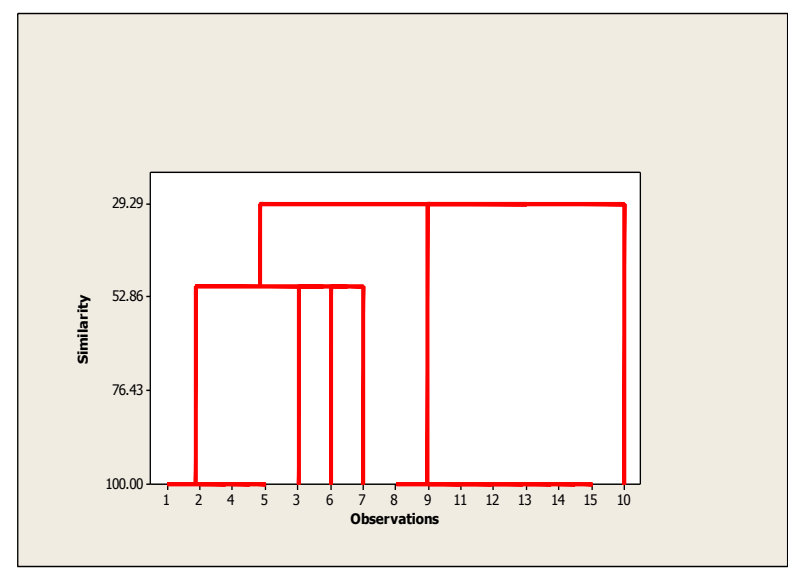

Figure 5. The similarities among the isolates-115 are the isolates collected from North Western Province and Western Province-Minitab 15

\section{Antagonistic effect of $T$. viride on $C$. paradoxa}

The time taken for the first contact of $T$. viride with all different $C$. paradoxa isolates was $48 \mathrm{~h}$ indicating that the radial growth rate of $T$. viride is equal in all combinations in the dual cultures. It was also observed that the growth of 
C. paradoxa isolates lessened as soon as they first contacted with $T$. viride which then rapidly overgrew on these colonies. The complete invasion and sporulation of $T$. viridae occurred after 6-7 days of incubation at room temperature $\left(28 \pm 1^{\circ} \mathrm{C}\right)$.

Mycoparasitism towards pathogenic fungi by Trichoderma species is proposed as a mechanism of bio control. For this ability several enzymes are involved. The prominent mechanism is that the degradation of cell wall constituents, prior to lysis the cells before chemotropic growth and coiling take place (Chet et al., 1998).

Table 2. Dual cultures antagonistic effect of $T$. viridae vs $C$. paradoxa isolates

\begin{tabular}{|c|c|c|c|}
\hline No. & $\begin{array}{l}\text { Original } \\
\text { location }\end{array}$ & Isolate & $\begin{array}{l}\text { Up to } 6 \text { days } \\
\text { \% inhibition }\end{array}$ \\
\hline 1 & \multirow{5}{*}{$\begin{array}{c}\text { North Western } \\
\text { province } \\
\text { Lunuwila/ } \\
\text { Dunkannawa }\end{array}$} & Lu 1 & $83 \%$ \\
\hline 2 & & $\mathrm{Lu} 2$ & $83 \%$ \\
\hline 3 & & Du 3 & $83 \%$ \\
\hline 4 & & Du 4 & $83 \%$ \\
\hline 5 & & LuCR 5 & $83 \%$ \\
\hline 6 & \multirow{6}{*}{$\begin{array}{c}\text { North Western } \\
\text { province } \\
\text { Kurunagala }\end{array}$} & $\mathrm{Ku} 6$ & $83 \%$ \\
\hline 7 & & $\mathrm{Ku} 7$ & $100 \%$ \\
\hline 8 & & $\mathrm{Ku} 8$ & $100 \%$ \\
\hline 9 & & $\mathrm{Ku} 9$ & $100 \%$ \\
\hline 10 & & $\mathrm{Ku} 10$ & $83 \%$ \\
\hline 11 & & $\mathrm{Ku} 11$ & $100 \%$ \\
\hline 12 & \multirow{5}{*}{$\begin{array}{l}\text { Western } \\
\text { province } \\
\text { Mirigama }\end{array}$} & Mi 12 & $100 \%$ \\
\hline 13 & & Mi 13 & $100 \%$ \\
\hline 14 & & Mi 14 & $100 \%$ \\
\hline 15 & & Mi 15 & $100 \%$ \\
\hline 16 & & Mi 16 & $100 \%$ \\
\hline
\end{tabular}

Although the first contact between the pathogens and the antagonists seemed similar, the final completion of inhibition is not at all the same. The samples obtained at same locations showed similar time for the complete inhibition. Accordingly, the isolates from Lunuwila and Dunkannawa did not show complete inhibition up to seven days while the isolates from Kurunegala and Mirigama took six days.
The spore viability of $C$. paradoxa isolates in separate mixed cultures with $T$. viridae

In the controls the germination of chlamydospores started 7 hours after the inoculation (Figure 6). A considerable growth of hyphae was seen after 12 hours (Figure 7). In the mixed spore suspensions both Ceretocystis spores and Trichoderma spores were visible, but no germination was found in both types of spores (Figure 8).

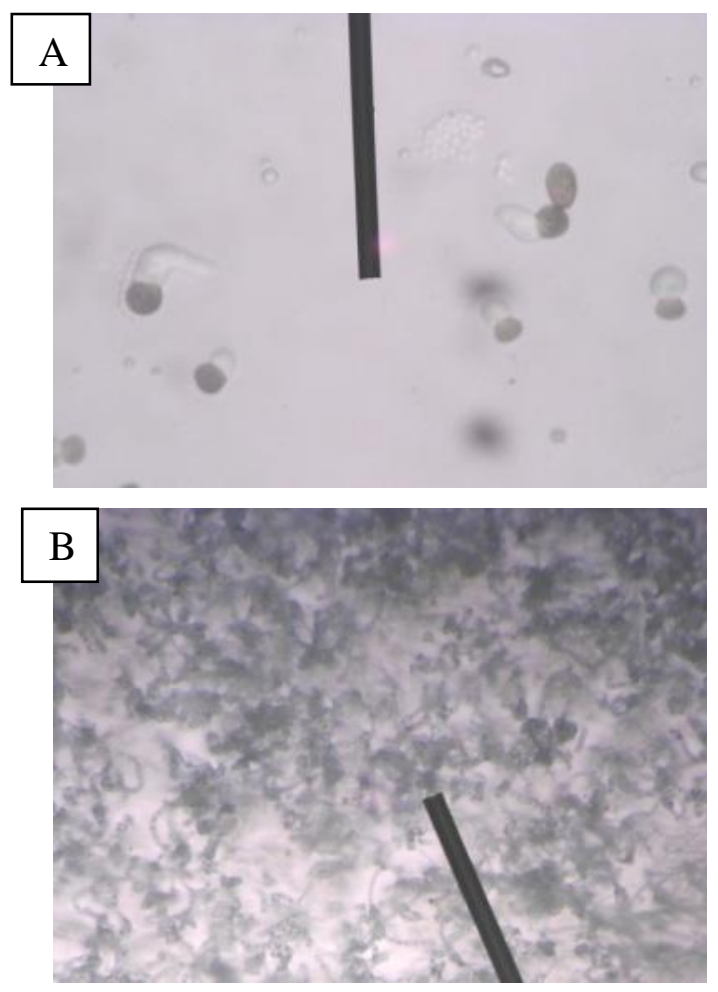

Figure 6. Germination of spores in separate suspensions. (A) Chlamydospores of C. paradoxa isolate, and (B) Germination of conidia of $T$. viridae

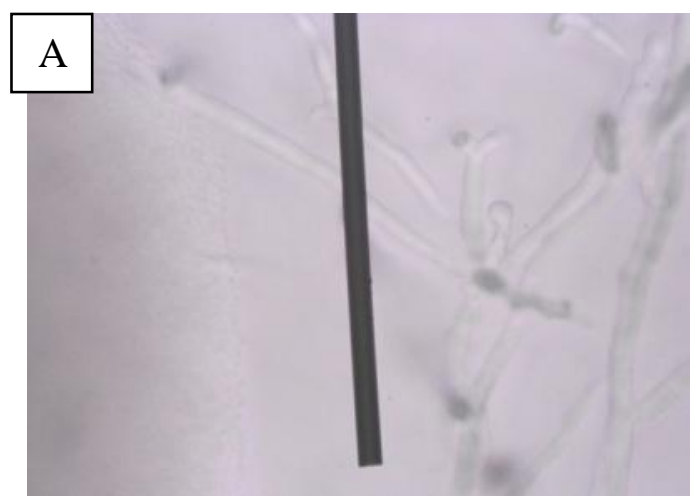




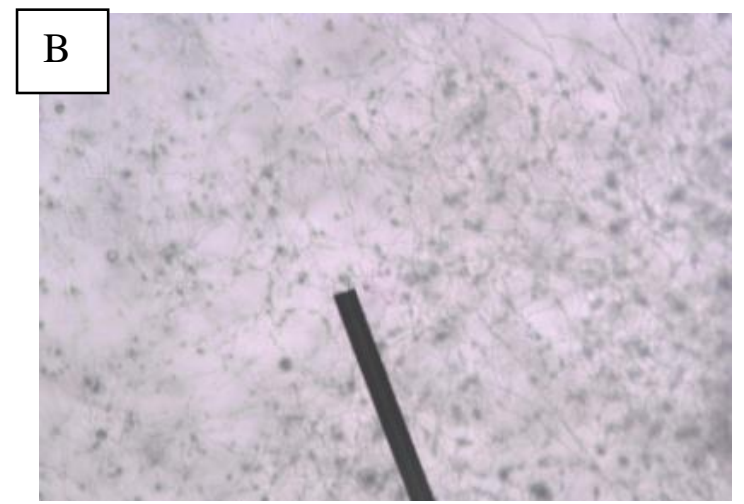

Figure 7. Growth of mycelial hyphae in separate suspensions. A. C. paradoxa isolate and B. T. viridae

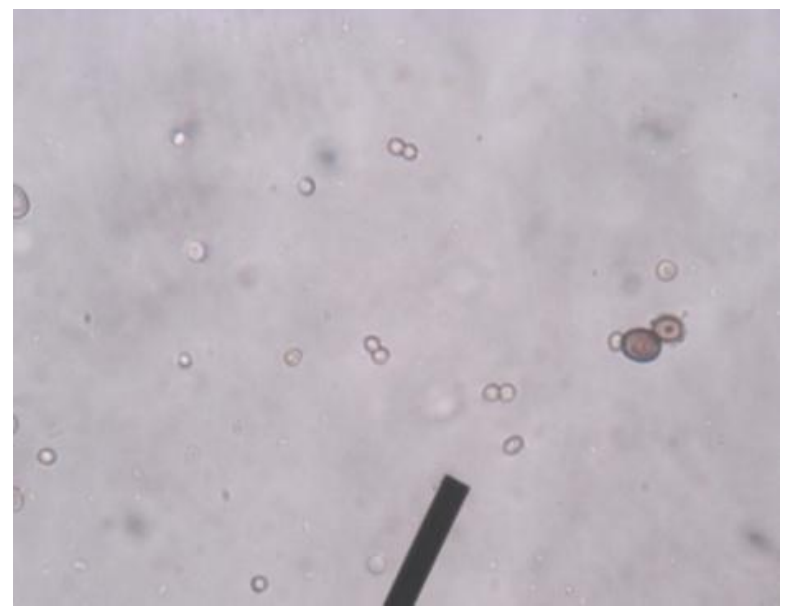

Figure 8. The presence of $C$. paradoxa chlamydospores and $T$. viridae conidia in the mixed suspension

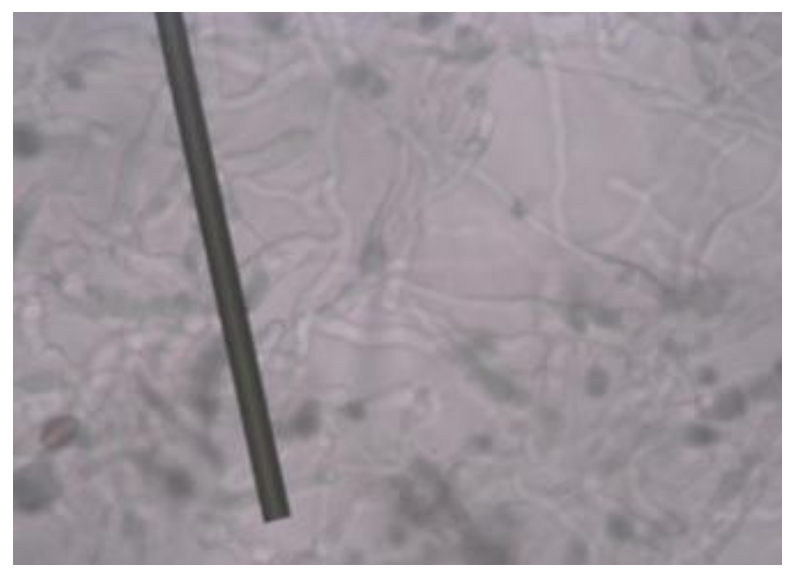

Figure 9. Germination of $T$. viride conidia in the mixed suspension
The subsequent results showed that only the Trichoderma spores were germinated when both are in the same suspension. The photographs taken in hourly intervals showed that only Trichoderma hyphae lengthened and chlamydospore of $C$. paradixa did not show germination and growth (Figure 9). According to the available literature, genus Trichoderma produces a variety of volatile and nonvolatile fungicidal metabolites making inhibitory effect on the germination of Ceratocystis spores (Dix $\&$ Webster, 1995).

It has been reported that Trichoderma can compete well with $C$. paradoxa for space, substrates, nutrients, and/or oxygen and the antagonist can win the competition easily inhibiting the others due to their fast growing nature (Bourguignton, 2008). This is one of the other reasons that Ceratocystis spores did not germinate, as the necessary conditions for their spore germination was inhibited by the competitive Trichoderma viridae.

\section{Effect of nonvolatile metabolites produced by $T$. viridae on $C$. paradoxa growth}

All isolates showed equal inhibition, after 5 days of incubation in dark showing no mycelial growth of $C$. paradoxa isolates unlike in the control plates in which $C$. paradoxa isolates showed confluent growth on the entire PDA plate at 5 days of incubation at room temperature $\left(28 \pm 1^{\circ} \mathrm{C}\right)$.

T. viridae completely inhibited the mycelial growth of $C$. paradoxa isolates at 12 days of exposure. Therefore, it was assumed that a diffusible non-volatile substance was responsible for the inhibition of $C$. paradoxa growth. The observation of this study is agreeable with Bourguington, 2008 who stated that species of Trichoderma produces nonvolatile metabolites, such as antibiotics and enzymes, which involve in inhibiting growth of pathogenic fungi and spore germination.

\section{Conclusion}

According to the results there are distinct morphological variations of $C$. paradoxa spores with respect to the geographical distribution of the pathogen showing three significant clusters. 
The two major clusters of the pathogen seemed evolved parallel and independently with the host confined to their agricultural environments. However, the third cluster; isolates 3, 6 and 7 shows the evolution of the pathogen outside its endemic agricultural environment due to manual dissemination of the pathogen through transportation of infected host plant materials. Meanwhile, isolate 10 shows distinctive evolution line from all other isolates. The experimental results revealed powerful antagonistic effects of $T$. viride in all the isolates of $C$. paradoxa. The complete inhibition of chlamydospore germination by the germinating conidia of $T$. viride in the mixed spore suspension, the overall invasion of $C$. paradoxa isolates by $T$. viride after 6-7 days of incubation at room temperature in the dual cultures and killing the vegetative growth of the isolates by the nonvolatile or diffusible metabolites released by $T$. viride suggest that there is a strong possibility to use as the antagonist to eliminate the pathogen from the raw materials used to produce coir and coir product for the export market.

\section{References}

Bourguignton, E. 2008., Ecology and diversity of indigenous Trichoderma species in vegetable cropping systems, National Centre for Advanced Bio-Protection Technologies, Lincoln University, Canterbury, New Zealand

Chet, I., Benhamou, N. \& Haran, S. 1998. Mycoparasitism and lytic enzymes. In Harman, GE, Kubicek, GE, Trichoderma and Gliocladium, Vol. 2. Enzymes, Biological control and Commercial Application, London, UK: Taylor and Francis Ltd. pp. 153-172.

Coomaraswamy, U. and de Fonseka, R. N. 1981. Hand book to the soil fungi of Sri Lanka.

Coomaraswamy, U. 1979. Hand book to the fungi parasitic on the plants of Sri Lanka.

Dennis, C. \& Webster, J, 1971. 'Antagonistic properties of species groups of Trichoderma III, Hyphal interactions',
Transactions of the British Mycological Society, Vol. 57, pp. 363-369.

Dix, N.J. \& Webster, J. 1995. Fungal Ecology, $1^{\text {st }}$ ed. London: London Academic Press

Dulce, R.N., Warwick \& Edson., Passos., E.M.O. 2009. Outbreak of stem bleeding in coconuts caused by Thielaviopsis paradoxa in Sergipe, Brazil. Tropical Plant Pathology, vol. 34, 3, 175-177

Egan, B. T. 1961. Report to the Government of Ceylon on the diseases of sugar cane in Ceylon.

Moutia, Y. \& Saumtally, S. 1999., Detection from soil and distribution of Ceratocystisparadoxa Moreau, causal agent of the pineapple disease of sugarcane, In: Lalouette, JA, Bachraz, DY, Sukurdeep, N (eds), Proceedings of the Fourth Annual Meeting of Agricultural Scientists 1999, Reduit, Mauritius, 21-22 October 1999, Reduit, Mauritius: Food and Agricultural Research Council, pp.75-82.

Patch, T. 1906. Diseases of coconut palm. Trophical Agriculturist 27:489-491.

Paulin-Mahady, A, E., Harrington, T.C. \& McNew, D.L. 2002. 'Phylogenetic and taxonomic evaluation of Chalara, Chalaropsis, and Thielaviopsis anamorphs associated with Ceratocystis', Mycologia, vol. 94, pp. 62-72.

Płaza, G.A., Upchurch, R., Brigmon, R.L., Whitman, W. B., \& Ulfig, K. 2003. Rapid DNA Extraction for screening soil filamentous fungi using PCR amplification. Polish Journal of Environmental Studies Vol. 13, No. 3 (2004), 315-318.

Ploetz, R.C. 2008. Tropical fruit crops and the diseases that affect their production, International commission on tropical biology and natural resources, Encyclopedia of Life Support System (EOLSS), viewed 12 July 2012 <www.eoless.net/ebooks/sample\%20Chap ters/c20/E6-142-TA-05.pdf>. 
Cord 2015, 31 (2)

Sanchez, V., Rebolledo, O., Picaso, R.M., Cardenas, E., Cordova, J., \& Samuels, G.J. 2007. 'In vitro antagonism of Theieloviopsis paradoxa by Trichoderma longibrachiatu', Mycopathologia, vol. 163 , pp. 49-58. 